\title{
Is There Anything "New" in Management?
}

\author{
Robert M. Fulmer, Trinity University \\ Daniel A. Wren, University of Oklahoma
}

Two books separated by 36 years between publication dates, and both titled "The New Management," are examined in this paper. The authors present the conventional wisdom of management in 1938 and compare it with the "New Management" of 1974. The question the authors seek to answer is the title of this paper, "Is There Anything 'New' in Management?' By comparing the two periods, the authors conclude: (1) that the problems facing management have remained essentially the same; (2) that there have been a refinement of techniques and further extensions of knowledge in the field of management; but (3) that there is really very little that can be called "new."

\section{INTRODUCTION}

One year ago, at these meetings of the Southern Management Association, the discussion turned to what was really "new" in management thought. The issues raised involved questions such as: Are we rediscovering old truths, once discussed and then lost on the dusty shelves of libraries? Do we advocate "new" approaches and invent jargon to solve problems that have existed ever since persons sought to cooperate in the service of purposeful endeavors?

To illustrate the dilemma, Ted Smith of the University of Georgia spoke on what he called the "motivation decrement." His phrase, "motivation decrement," is a modern invention - the phenomenon it describes is in fact a very old one. Frederick Taylor used the term "soldiering" to report his observations on workers doing less than their skills and capabilities enabled them to do. To solve the problem of his time, Taylor advocated work measurement, piece-rate payment plans, scientific personnel selection, functional foremen, and a mental revolution to overcome the effects of soldiering. His reasoning was that the workers' motivation to soldier would be overcome, i.e. the "decrement" reduced, if the worker knew the standard was set fairly and that he would be rewarded for additional output. Dr. Smith, our modern parallel, advocated improved work design and intrinsic motivational systems to get workers to produce more. The problem of 
motivating has remained through the generations; only the proposed solutions have changed.

It was toward this background of old problems and "new solutions" that the authors turned their attention. One of us recently wrote a book called The New Management (1974); [1] the other noted that there existed another book called The New Management, published in 1938. [2] What, then, was really "new"? Were the problems essentially the same over this 36 year span of management history? If so, how did the solutions vary?

\section{THE NEW MANAGEMENT, 1938}

The New Management of 1938 was co-authored by two Englishmen and one German, all of whom had a background in engineering and taught in the area of what was then called industrial administration. Meyenberg was the most widely known of the three since he had introduced the ideas of Frederick W. Taylor in Germany. With the advent of Hitler, Meyenberg fled to England in 1933 and became a professor and consultant. The authors stated that their industrial experiences were drawn from America and Germany as well as Great Britain. They drew heavily upon the American literature in their writing, reflecting the prevailing conventional wisdom of those times with respect to scientific management and its industrial administration flavor. They stated their purpose as that of synthesis, bringing together the current state of the art as reflected in the management literature. They raised the question of why they called their book The New Management and answered: [2, p.viii]

"for the reason that it is written in the light of the new spirit that has appeared in industry during the present century: the spirit that has grown and spread so beneficently, sweetening the relations between all those engaged in industry to the general good; the spirit of friendship and willing cooperation between owners, management and workers . . . and with humanity as an interested spectator."

From this opening, the authors turned their attention to "the new spirit" in industry and how it involved the utilization of scientific management in industry. The "modern" manager (1938), they advised, relied more upon scientific aids and systems, but the success of these tools was dependent solely upon the quality of leadership in the organization. To control others, they said, a manager must first learn to control himself, a maxim that Socrates proposed some 30 centuries ago. They offered the position common to the times that it is the qualities or traits of the leader that are important, and that faith and trust in one's fellow workers are all important. They tell us that the "gardener who spends all of his time pulling weeds will never grow flowers." The emphasis then was on developing the talents of the personnel rather than on stressing their faults.

The authors felt that management could never be a "science" until psychology could discover, classify, and accurately state the laws that govern human beings. They held forth the hope, however, that what Taylor had brought to industry in terms of experimentation, standardization, methods, and so on, could someday be equalled by advances in psychology. The "New Management" would combine these fields, making industry economically efficient as well as humanly satisfying. 
With this theme of combining scientific management and psychology, the authors offered some typical managerial problems of 1938:

1. Organization - defining the duties of people, finding the right people to perform these duties, and assigning responsibility.

2. The environment of management - managers were responsible to those who owned the business. The authors did mention the need for cooperation between firms within an industry, but there was little or no recognition of a social environment of management. In their view, a society would benefit through the economic efficiency of industry.

3. Division of labor - essential to productivity, as well as enabling the manager to determine who is responsible for what activities.

4. Personnel - discussed under the term of "welfare," with due caution needing to be exercised that the workers do not become "spoiled," nor does management infringe too much on the private lives of the workers.

5. Committees - should be used for consultation, they advised, but should never be given any authority. They should not be allowed too much time for debate, nor should they be given control over any activities.

6. Psychology - this discussion focused on the analysis of work, the working conditions, the nature of the job, and defining the qualities that workers must possess. It was industrial psychology, focusing upon the selection, testing, and training of workers. The person was to be fitted to the job as it was designed through time and motion study.

7. Motivation - in a case study of a cigarette factory, the authors cited the differences in productivity before and after the introduction of scientific work studied. Motivation was primarily economic, involving the application of a piece work bonus system after jobs had been studied, vocational tests used in personnel selection, and training accomplished in standardized methods. The authors did note that "tacit agreements" between workers often retarded production, indicating they were aware of informal groups and works norms.

8. Safety - would be improved by standard work methods, improved personnel selection, and better training of workers.

\section{THE NEW MANAGEMENT, 1974}

The New Management of 1974 claimed the title of "newness" although the author stated that there was "no radically new information between its covers." The author suggested that the new management was "new" in somewhat the same sense as the new math and the new grammar were when they first appeared. The presentation, more than the basic data, was seen as innovative.

The specific features which justify the title were explained as follows:

1. It was the first book consciously to bridge the gap between the study of the humanities and the study of business. It was the author's hope that the student would thus be comfortably drawn from the familiar subject matter studied in his first college courses to the unfamiliar field of management and made to see the interrelationship between business and the social sciences. The study of management would become a clear continuation of his earlier education but give that education a professional slant. 
2. It discussed management theory with an emphasis on the future, because most students will be applying the concepts taught here over a period of many years.

A year later (in 1975), one of the authors conducted a micro-survey among leading members of the Academy of Management to inquire about the nature and significance of "new" developments during the 1970's. As a result, this preliminary effort indicated that a full-blown study would not be productive. Essentially, the responses suggested that important new developments-either for the beginning management student or for the $\mathrm{Ph} . \mathrm{D}$. candidate-would fall into one of four categories:

1. Recognition of Management's Complexity. Several of the respondents indicated that there has been a wider recognition that management cannot be reduced to a series of universally applicable laws. The contingency approach, although recognized considerably earlier, had come into its own during the '70's.

2. Refinement of Techniques. Such well established management techniques as MBO, Delphi forecasting and several quantitative techniques have been significantly refined during the past six years. Again, the emphasis has been on improving and extending existing management techniques rather than on the development of totally new tools.

3. An Extension of Knowledge. As suggested by the two previous concepts, there have been several areas in which knowledge has been confirmed and extended. One major area deals with the contingency approach. Others would include a knowledge about human learning and motivation.

4. New Techniques. Although the respondents seemed to appreciate the significance of its development, the only specific technique mentioned as having developed during this decade was Nominal Group Process. Of course, the foundations for this (with Delphi) had originated considerably earlier.

\section{ARE RECENT DEVELOPMENTS REALLY “NEW"?}

1. Contingency theory-Fayol noted in 1916 that his principles were guides, "light houses," and must be modified to fit changing conditions. Further, Mary Follett's "law of the situation" was a precursor of both MBO and contingency theory.

2. Computers-A product of the early 1800 's and Charles Babbage, although recent refinements and extensions are apparent.

3. Equity theory of motivation-early 1920's and Whiting Williams' idea that pay is relative to the worker.

4. Organizational Behavior-the continuing search for more "science" in the study of behavior in organizations. The "New Management" of 1938 felt that it was possible; but if one studies the Presidential address of Lyman Porter to the Academy in 1974, he wonders how much progress we have really made.

\section{CONCLUSION}

The time period spanned by the two "New Management" books discussed here reflects some shifts but no radical innovations in management. We 
have learned more, we have extended and refined our knowledge, but many of the basic problems in management remain with us. Our tools and concepts have been sharpened with experience and research, as they should be, but we continue to stand on the shoulders of the pioneers who opened the new vistas in management thought. The French philosopher-historian Montesquieu tells us that "The more things change, the more they remain the same." Or as an older source says, "That which has been is that which shall be; and that which has been done is that which shall be done: and there is no new thing under the sun." (Ecclesiastes 1:9, ASV).

\section{REFERENCES}

[1] Fulmer, Robert M., The New Management (New York: The MacMillan Company, 1974).

[2] Hildage, H. T., Marple, T.G., and Meyenberg, F. L, The New Management (London: McDonald and Evans, 1938). 